\title{
Food intake behaviours in obese versus non obese adults; an observational study
}

\author{
H. Spence ${ }^{1}$, A. McElroy ${ }^{1}$, M.A. Kerr ${ }^{1}$, C. Gill ${ }^{1}$, J. Sittlington ${ }^{1}$, C.W. Le Roux ${ }^{2}$, \\ M.B.E. Livingstone ${ }^{1}$ and R.K Price ${ }^{\mathrm{T}}$ \\ ${ }^{1}$ Nutrition Innovation Centre for Food and Health (NICHE), Ulster University, Coleraine, UK and \\ ${ }^{2}$ Diabetes Complications Research Centre University College Dublin, Ireland
}

Obesity is a complex and debilitating disease driven primarily by a chronic positive energy balance ${ }^{(1)}$. Several food behaviours have been associated with obesity including excess energy dense food intake, higher eating rate, increased frequency of eating and eating later in the day ${ }^{(2)}$, however few studies have objectively measured food behaviours to evaluate these associations. The aim of this research was to investigate differences in food intake and eating behaviours between individuals categorised as obese (BMI $>30$ ) and those with $\mathrm{BMI}<30$.

Participants included are those undertaking an ongoing long-term study (5-years) to determine eating behaviours following bariatric surgery. 41 obese/morbidly obese participants (46.9 \pm 11.0 years, BMI: $43.0 \pm 8.7 \mathrm{~g} / \mathrm{m} 2$, gender: $28 \mathrm{~F}, 13 \mathrm{M})$ and 24 non-obese participants $(39.9 \pm 14.4$ years, BMI: $25.1 \pm 3.4 \mathrm{~kg} / \mathrm{m} 2$, gender: $11 \mathrm{~F}, 13 \mathrm{M})$ completed a two-night stay within the Human Intervention Studies Unit at Ulster University, Coleraine campus. Measurements included 24-hour energy intake (EI)(MJ), energy density (ED) $(\mathrm{kJ} / \mathrm{g}), \%$ nutrient contribution to total EI and eating behaviours; speed (kJ/min), timing of eating, number (n), duration (mins) of eating occasions (defined as consumption of at least $210 \mathrm{~kJ}$ separated by preceding or future eating occasions by $>5$ minutes) and timing of eating (food intake recorded over four epochs: 7-11am, 11:01-3pm, 3:01-7pm and 7:01-11pm). Over the 24 hour period participants were provided with ad lib access to food and snacks representing a range of low /high fat macronutrient mix food groups with varying $\mathrm{CHO}$ and protein content ${ }^{(3)}$. Food intake was measured using covert weighing techniques validated by closed-circuit television.

Total EI was significantly higher in obese v non obese adults $(18.6 \pm 7.4 \mathrm{MJ} /$ day vs $15.0 \pm 3.8 \mathrm{MJ} /$ day, $\mathrm{p}=0.04)$, however total ED $(4.6 \pm 1.4 \mathrm{vs} 5.0 \pm 1.6 \mathrm{~kJ} / \mathrm{g}, \mathrm{p}=0.36)$ or percentage EI from individual macronutrients (carbohydrate, sugar, protein, fat and saturated fat) did not significantly differ between groups $(\mathrm{p}>0.05)$. In regards eating behaviour, there were no differences between obese $\mathrm{v}$ non-obese adults in: EI per eating occasion $(2615.5 \pm 1304.4$ vs $2733.5 \pm 1259.9 \mathrm{~kJ}, \mathrm{p}=0.77)$, speed of eating (163.1 \pm 94.4 vs $161.2 \pm 45.4 \mathrm{~kJ} / \mathrm{min}, \mathrm{p}=0.93)$ or duration of eating occasions $(59.8 \pm 42.8$ vs $52.1 \pm 48.2 \mathrm{mins}, \mathrm{p}=0.52)$. Additionally, the total number of eating occasions did not differ significantly between obese v non-obese adults $(9.2 \pm 3.2$ vs $8.3 \pm 2.7$, p $=0.24)$ or across the 4 epochs $(2.2 \pm 1.1$ vs $1.9 \pm 0.9,2.5 \pm 1.2$ vs $2.1 \pm 1.1,2.3 \pm 1.1$ vs $2.4 \pm 1.0,2.3 \pm 1.6$ vs $1.9 \pm 1.5, p=>0.20)$.

These findings provide important insights into eating behaviour differences in obese v non-obese adults. Food quantity could be a more important driver of obesity over and above food type or eating behaviour. The findings presented highlight a need to strengthen strategies to improve portion control and mechanisms to regulate appetite within public health obesity related interventions ${ }^{(4)}$. However more research is warranted in a larger cohort to confirm these findings, and also to examine the longer-term effects of the observations.

\section{References}

1. Hruby A \& Hu FB (2016) Pharmacoeconomics 33, 673-689

2. Aparicio A, et al. (2017) Public Health Nutr 20(13), 2364-2373

3. Geiselman PJ, et al. (1998) Physiol Behav 63, 919-28

4. Livingstone MBE \& Pourshahidi LK (2014) Nutrition 5, 829-834 